\title{
RANCANG BANGUN ANTENA BICONICAL UHF UNTUK APLIKASI KANAL TV
}

\author{
Widya Purwanti Mahardhika ${ }^{1}$, Budi Aswoyo ${ }^{2}$, Akuwan Saleh ${ }^{2}$ \\ ${ }^{1}$ Mahasiswa Politeknik Elektronika Negeri Surabaya, Jurusan Teknik Telekomunikasi \\ ${ }^{2}$ Dosen Politeknik Elektronika Negeri Surabaya Institut Teknologi Sepuluh Nopember \\ Kampus ITS, Surabaya 60111 \\ e-mail : mahardhika@yahoo.com e-mail : $\underline{\text { Budias@eepis-its.edu, akuwan@eepis-its.edu }}$
}

\begin{abstract}
Abstrak
Dalam kehidupan sehari-hari, kita sering menemukan sinyal lemah yang diterima oleh sebuah antena TV yang menyebabkan gambar tidak jelas. Untuk mengatasi masalah tersebut, kita harus memutar-mutar antena untuk mendapatkan sinyal yang bagus. Oleh karena itu, akan dibuat antena Biconical dengan reflektor sudut $90^{\circ}$ untuk mendapatkan pola radiasi yang directional, yang diintegrasikan dengan motor stepper dan dikontrol oleh mikrokontroler, sehingga antena tersebut dapat tracking untuk mencari daerah yang mempunyai sinyal paling bagus dengan memperhitungkan nilai level daya dari tiap - tiap derajat posisi antenna pada masing - masing kanal TV, yaitu dari posisi $0^{\circ}$ sampai $360^{\circ}$ dengan step $5^{\circ}$.

Untuk membuat antenna Biconical diperlukan dimensi - dimensi yang sesuai, yaitu panjang masing - masing kerucut antenna sebesar $15 \mathrm{~cm}$ dengan besar sudut kerucut $60^{\circ}$ dan diameter kerucut $7,5 \mathrm{~cm}$. Kemudian untuk panjang dan lebar reflektor sudut $90^{\circ}$ adalah $45 \mathrm{~cm}$ dan $31,8 \mathrm{~cm}$. Antena Biconical dibuat dari lembaran tembaga. Sedangkan reflektor sudutnya dibuat dari lembaran aluminium.

Selanjutnya dilakukan pengukuran terhadap masing - masing kanal TV untuk memperoleh level daya yang nantinya digunakan untuk mengetahui perbedaan pola radiasi yang menggunakan dan tidak menggunakan reflektor sudut $90^{\circ}$, side lobe level dan Half Power Beamwidth (HPBW). Saat antena menggunakan reflektor sudut $90^{\circ}$, maka HPBW terbesar ada pada kanal Trans7, yaitu 94, dan HPBW terkecil berada pada kanal SpaceT, yaitu 9. Sedangkan untuk antena yang tidak menggunakan reflektor sudut $90^{\circ}$, HPBW terbesar ada pada kanal Tvone, yaitu 88 , sedangkan HPBW terkecil ada pada kanal MetroTV, yaitu 16. Untuk Side Lobe Level (SLL) terbesar, saat antena menggunakan reflektor sudut $90^{\circ}$ berada pada kanal JTV dan ANTV, yaitu 1,37 dan SLL terkecil berada pada kanal RCTI, yaitu 0,02 . Sedangkan saat antena tidak menggunakan reflektor sudut $90^{\circ}$, maka SLL terbesar ada pada kanal SBO, yaitu 2,77, dan SLL terkecil ada pada kanal SCTV, yaitu 0 .
\end{abstract}

Kata kunci - Antena Biconical, Single Lobe, Reflektor Sudut, Spectrum Analyzer

\section{PENDAHULUAN}

Dalam era globalisasi seperti saat ini, tentunya teknologi telah berkembang pesat, menyebabkan semua hal telah menjadi kebutuhan untuk melengkapi kehidupan kita. Semua orang menginginkan sesuatu yang mudah dan praktis untuk mendapatkan hasil yang memuaskan. Saat ini, antena merupakan peralatan yang sangat vital dalam dunia telekomunikasi. Antena mempunyai banyak ragam dengan karakteristik dan fungsi yang berbeda - beda. Salah satu fungsi antena di sini adalah sebagai antena TV untuk pencarian sebuah kanal TV. Dalam hal ini antena yang digunakan adalah antena Biconical.

Dalam kehidupan sehari - hari kita sering menemukan sinyal lemah yang diterima oleh sebuah antena TV yang menyebabkan gambar tidak jelas. Untuk mengatasi masalah tersebut kita harus memutar - mutar antena agar bisa mendapatkan sinyal yang bagus sehingga menghasilkan gambar yang bagus pula. Kemudian dari situlah, akan dibuat sebuah antena TV dan diintegrasikan dengan motor stepper yang dikontrol oleh mikrokontroler, sehingga antena tersebut dapat tracking untuk mencari daerah yang mempunyai sinyal paling bagus dengan main lobe terbesar.

\section{TEORI PENUNJANG}

\subsection{Antena Biconical}

Antena Biconical [3] merupakan sebuah antena yang memiliki bentuk yang terdiri dari 2 buah kerucut, yang digunakan untuk menangkap sinyal UHF TV. Antena ini memiliki pola radiasi seperti koordinat bola. Gelombang yang ditangkap akan menghasilkan arus pada kerucut dan tegangan yang berada diantara 2 kerucut tersebut. Maka impedansi dari antena Biconical adalah tegangan dibagi arus pada antena tersebut.

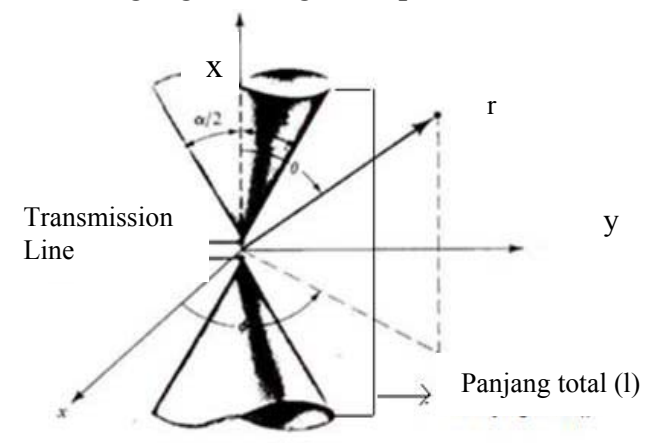

Gambar 1. Antena Biconical Geometri 
Untuk $\frac{\alpha}{2}$ mempunyai nilai $30^{\circ}[1]$, sedangkan untuk nilai nilai $\mathrm{r}$ didapatkan dari $\mathrm{r}=\frac{l}{2}$, dimana 1 merupakan panjang total.

Dalam hal ini, untuk menentukan panjang kerucut (1), maka digunakan rumus sebagai berikut :

$$
\begin{aligned}
& \lambda=\frac{c}{f} \\
& 1_{\text {total }}=\frac{\lambda}{2}
\end{aligned}
$$

$1_{\text {masing-masing kerucut }}=\frac{\lambda}{4}$

Berdasarkan Gambar 1, Antena Biconical memiliki analisa sinyal yang hampir sama dengan antena dipole. Akan tetapi, antena Biconical memiliki sifat intermediet bandwidth, yang mana cocok untuk antena TV[1].

Penggunaan sebuah antena didalam sistem pemancar ataupun penerima selalu dibatasi oleh daerah frekuensi kerjanya. Pada range frekuensi kerja tersebut, antena diusahakan dapat bekerja dengan efektif agar dapat menerima dan memancarkan gelombang elektromagnetik pada band frekuensi tertentu. Pengertian harus dapat bekerja dengan efektif disini adalah bahwa distribusi arus dan impedansi dari antena pada range frekuensi tersebut benar-benar belum mengalami perubahan yang berarti, sehingga masih sesuai dengan pola radiasi yang direncanakan. Lebar band frekuensi atau dikenal sebagai bandwidth antenna adalah range frekuensi kerja dimana antena masih dapat bekerja dengan efektif.

Bandwidth sebuah antenna dapat dirumuskan sebagai berikut :

$B W=f_{u}-f_{L}(H z)$

atau

$\mathrm{BW}=\left(\frac{f(\text { high })-f(\text { low })}{f(\text { high })}\right) \times 100$

\subsection{Reflektor Sudut $90^{\circ}$}

Dalam hal ini digunakan reflektor sudut $90^{\circ}$ [1], karena karakteristik radiasinya sangat menarik, sehingga menjadi sangat populer, selain itu reflektor sudut tersebut digunakan untuk optimasi penerimaan sinyal TV.
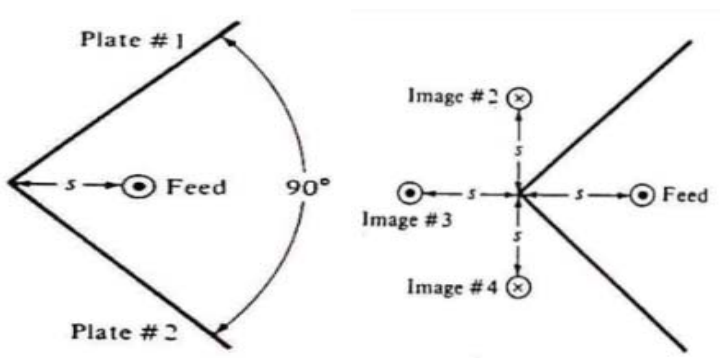

b) Penggambaran reflektor sudut $90^{\circ}$

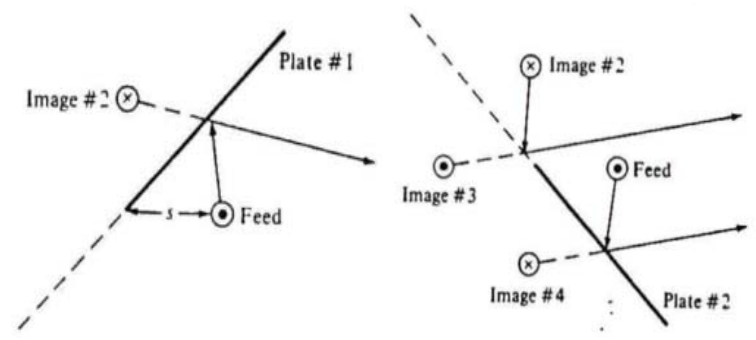

a) Penggambaran Reflektor sudut $90^{\circ}$ disertai image

Gambar 2. Penggambaran geometris dan polarisasi elektrik dari image untuk reflektor sudut $90^{\circ}$

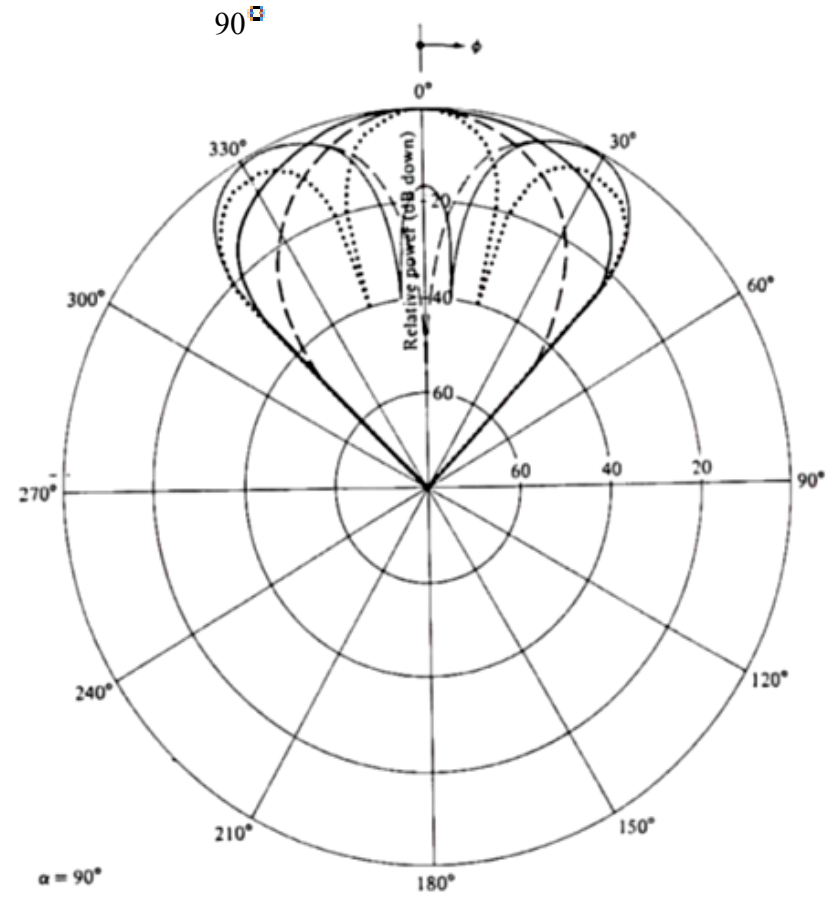

Gambar 3. Amplitudo Radiasi Ternormalisasi untuk

$$
\alpha=90^{\circ}
$$

Untuk mendapatkan beberapa informasi tentang kinerja dari sudut reflektor, disini akan ditampilkan pola normalisasi untuk sudut reflektor $90^{\circ}$ dengan jarak dari $\mathrm{s}=0,1 \boldsymbol{\lambda} ; 0,7 \boldsymbol{\lambda}$; $0,8 \boldsymbol{\lambda} ; 0,9 \boldsymbol{\lambda} ; 1,0 \boldsymbol{\lambda}$. Hal itu sudah jelas untuk jarak yang kecil terdiri dari single lobe utama untuk ditampilkan dengan jarak yang lebih besar ( $\mathrm{s}>$ $0,7 \boldsymbol{\lambda}$ ) untuk $\mathrm{s}=\boldsymbol{\lambda}$ pola dari dua lobes dipisahkan dengan null sepanjang garis $\mathrm{x}\left(\phi=0^{\circ}\right)$. Parameter lain untuk sudut reflektor adalah menguatkan di sepanjang bidang $\mathrm{x}\left(\phi=90^{\circ}, \phi=0^{\circ}\right)$ sebagai fungsi dari feed ke puncak dengan jarak s [6]. Normalisasi (relatif terhadap bidang satu elemen yang terisolasi) dengan kekuatan bidang yang absolute $\left|\mathrm{E} / \mathrm{E}_{0}\right|$ sebagai fungsi dari $\frac{s}{\lambda}(0 \leq \mathrm{s} \leq 10$ $\lambda$ ) untuk $\alpha=90^{\circ}$. 


\section{METODOLOGI}

\subsection{Perencanaan Sistem}

Dalam pengerjaan antena ini, akan dibuat sebuah antena Biconical dengan spesifikasi sebagai berikut :

- Antena Biconical memiiki dua kerucut sebagai penerima sinyal, dalam hal ini sinyal TV.

- Antena Biconical menggunakan splitter Booster sebagai penguat sinyal.

- Antena Biconical disertai reflektor sudut $90^{\circ}$ untuk mendapatkan pola radisi yang teraarah (directional).

\subsection{Perancangan Sistem}

Untuk merancang antenna Biconical, ada beberapa yang harus ditentukan, yaitu :

\section{- Panjang kerucut antena}

Panjang total kedua kerucut :

$$
1_{\text {total }}=\frac{\lambda}{2}
$$

Panjang masing-masing kerucut :

$$
1_{\text {masing-masing kerucut }}=\frac{\lambda}{4}
$$

Dari persamaan (5) dan (6), untuk mencari panjang kerucut terlebih dahulu harus menentukan panjang gelombangnya, dengan $\mathrm{c}=3 \times 10^{8}$ dan frekuensi UHF $=500 \mathrm{Mhz}$, sehingga :

$$
\begin{aligned}
& \lambda=\frac{c}{f}==0,6 \mathrm{~m}=60 \mathrm{~cm} \\
& 1=\frac{60 \mathrm{~cm}}{2}=30 \mathrm{~cm} \\
& 1_{\text {masing-masing kerucut }=} \frac{\lambda}{4}=15 \mathrm{~cm}
\end{aligned}
$$

- Besar sudut dan Panjang diameter pada masing - masing kerucut

$$
\begin{aligned}
\text { jari-jari }(\mathrm{r}) & =\sin 30^{\circ} \times 15 \\
& =7,5 \mathrm{~cm} \\
\operatorname{diameter}(\mathrm{x}) & =2 \mathrm{r} \\
& =2 \times 7,5 \\
& =15 \mathrm{~cm} \\
\operatorname{tinggi}(\mathrm{t}) \quad & =\cos 30^{\circ} \times 15 \\
& =12,9 \mathrm{~cm}
\end{aligned}
$$
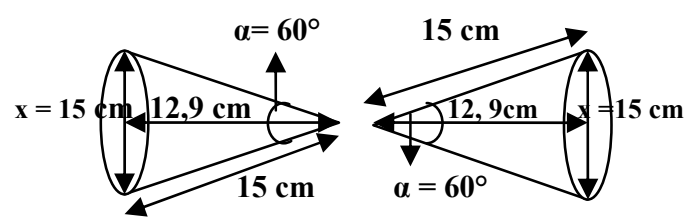

Gambar 4. Ukuran 2 Kerucut pada Antena Biconical

\section{- Jarak antara 2 kerucut}

Pada antena Biconical terdapat 2 buah kerucut, dimana jarak antar 2 kerucut tersebut didapatkan berdasarkan rumusan di bawah ini [1] :

$\frac{l}{d} \gg 1$

$\mathrm{d} \ll \lambda$

Dimana :

$\lambda=\frac{c}{f}=\frac{3 \times 10^{8}}{5 \times 10^{8}}=0,6 \mathrm{~m}=60 \mathrm{~cm}$

Sehingga diambil nilai $\mathrm{d}=1 \mathrm{~cm}$

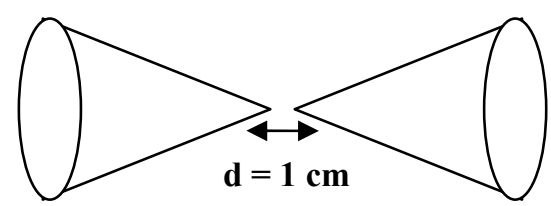

Gambar 5. Jarak Antara 2 Kerucut Antena Biconical

\section{Reflektor Sudut}

Perhitungan reflektor sudut ini didasarkan pada panjang gelombang $(\lambda)$, dengan frekuensi $450 \mathrm{Mhz}[1]$.

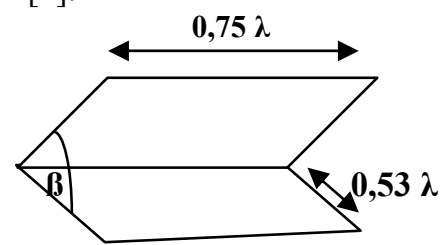

Gambar 6. Reflektor Sudut dengan ukuran yang telah ditentukan

\section{Hasil Perancangan}

Dari gambar reflektor sudut, akan dihitung rasio panjang gelombang $(\boldsymbol{\lambda})$, dengan frekuensi $450 \mathrm{Mhz}$ (hanya sebagai acuan untuk mendapatkan ukuran sebenarnya, sehingga mempermudah untuk membuat antena Biconical. Maka :

$$
\lambda_{\mathrm{L}}=\frac{c}{f}=\frac{3 \times 10^{8}}{4,5 \times 10^{8}}=66 \mathrm{~cm}
$$

Sehingga akan didapatkan ratio :

Panjang reflektor $=\frac{50 \mathrm{~cm}}{66 \mathrm{~cm}}=0,75 \lambda$

Lebar reflektor $=\frac{75 \mathrm{~cm}}{66 \mathrm{~cm}}=0,53 \lambda$

\section{Desain pada frekuensi center}

Kemudian dari acuan perhitungan, maka akan dibuat reflektor sesungguhnya pada antena Biconical, dengan ukuran sebagai berikut :

$\mathrm{f}_{\mathrm{L}}=300 \mathrm{Mhz}$
$\mathrm{f}_{\mathrm{H}}=700 \mathrm{Mhz}$

$$
\mathrm{f}_{\text {center }}=\frac{700+300}{2}=500 \mathrm{Mhz}
$$




$$
\lambda=60 \mathrm{~cm}
$$

Panjang reflektor $=0,75 \lambda=0,75 \times 60=45 \mathrm{~cm}$ Lebar reflektor $=0,53 \lambda=0,53 \times 60=31,8 \mathrm{~cm}$

Sehingga gambaran reflektor sudut sebenarnya yang dibuat untuk antena Biconical adalah sebagai berikut :

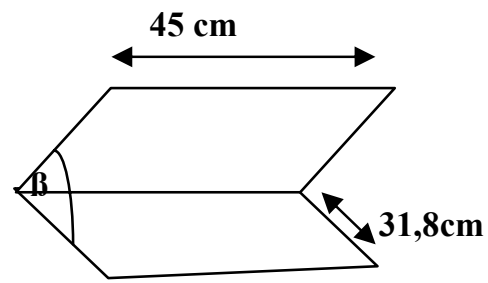

Gambar 7. Reflektor sudut sebenarnya yang akan dibuat untuk antena Biconical

\section{PENGUJIAN DAN ANALISA}

Setelah melakukan pengukuran terhadap parameter antena, yaitu pola radiasi, maka pada tahap ini akan diamati level daya tiap $5^{\circ}$ pergerakan antena dari $0^{\circ}$ sampai $360^{\circ}$ pada frekuensi masing - masing kanal TV yang telah ditentukan, yaitu RCTI, SCTV, TPI, Indosiar, dan ANTV. Kemudian setelah level daya didapatkan, maka dicari normalisasinya dengan cara hasil pengamatan masing - masing level daya dikurangi dengan besar level daya saat berada di posisi $0^{\circ}$, sehingga saat posisi $360^{\circ}$ nilai normalisasinya akan sama dengan nol. Dari hasil normalisasi tersebut, maka pola radiasi masing - masing kanal TV akan dapat diketahui yaitu apabila menggunakan reflektor sudut maka pola radiasinya directional, sebaliknya, apabila tidak menggunakan reflektor sudut maka pola radiasinya omnidirectional.

Dari lima kanal TV yang sudah diteliti, HPBW terbesar ada pada kanal ANTV tanpa menggunakan reflektor sudut $90^{\circ}$ yaitu $69^{\circ}$, hal ini disebabkan sinyal yang ditangkap berasal dari segala arah sehingga bentuknya omnidirectional dan menyebabkan lebar sudut yang memisahkan beamwidthnya juga besar .

Untuk nilai Side Lobe Lavel (SLL) tertinggi berada pada kanal SCTV menggunakan reflektor sudut $90^{\circ}$ yaitu 0,1 , disebabkan pengaruh dari reflektor sudut $90^{\circ}$ yang membuat pola radiasi sinyal menjadi directional

\subsection{Pengukuran Pola Radiasi}

Setelah proses perancangan dan pembuatan antena Biconical,maka akan dilanjutkan dengan melakukan pengukuran pola radiasi dari antena tersebut, yang dalam hal ini menggunakan reflektor sudut $90^{\circ}$. Pengukuran pola radiasi dilakukan untuk mengetahui bagaimana bentuk pola radiasi dari antena Biconical yang telah dibuat. Selain itu yang paling penting adalah mengetahui seberapa jauh ketepatan perancangan antena sesuai dengan harapan. Tentunya diharapkan hasil dari pengukuran antena ini sesuai dengan teori, yaitu didapatkan pola radiasi yang single lobe. Untuk mendapatkan pola radiasi yang sesuai, maka ada beberapa hal yang harus diperhatikan,yaitu menghindari dari pantulan benda - benda yang ada di sekitar pengukuran, letak serta posisi dari antena tersebut dengan jarak dan ukuran reflektor yang sudah ditentukan. Pola radiasi suatu antena merupakan karakteristik yang menggambarkan sifat radiasi antena pada medan jauh sebagai fungsi arah. Arah disini adalah memutar antena dari arah $0^{\circ}$ sampai $360^{\circ}$ searah putaran jarum jam.

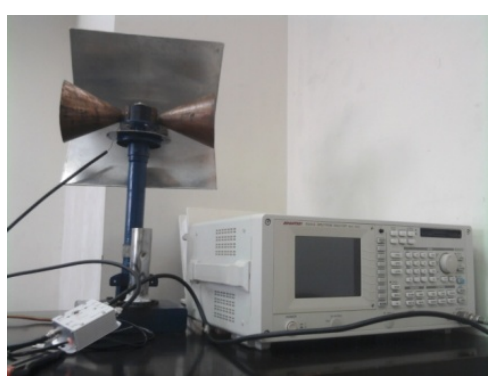

Gambar 8. Pengukuran dan Pengujian Antena Biconical

Pengukuran dan pengujian tersebut dilakukan dengan cara :

- Antena Biconical dihubungkan dengan kabel spliterr booster, kemudian dari spliterr booster masuk ke spectrum analyzer dan TV.

- Selanjutnya antena diputar setiap $5^{\circ}$ dimulai dari $0^{\circ}$ sampai $360^{\circ}$ (searah putaran jarum jam).

- Mengamati level daya tertinggi pada frekuensi kanal tv dan span yang telah ditentukan dari setiap pergerakan $5^{\circ}$ dari antena tersebut.

\subsection{Hasil Pengukuran Pola Radiasi}

Di bawah contoh pola radiasi yang dihasilkan oleh 5 dari 14 kanal TV yang telah diamati, yaitu 
Kanal SCTV pada frekuensi 572,25 Mhz tanpa reflektor sudut 90

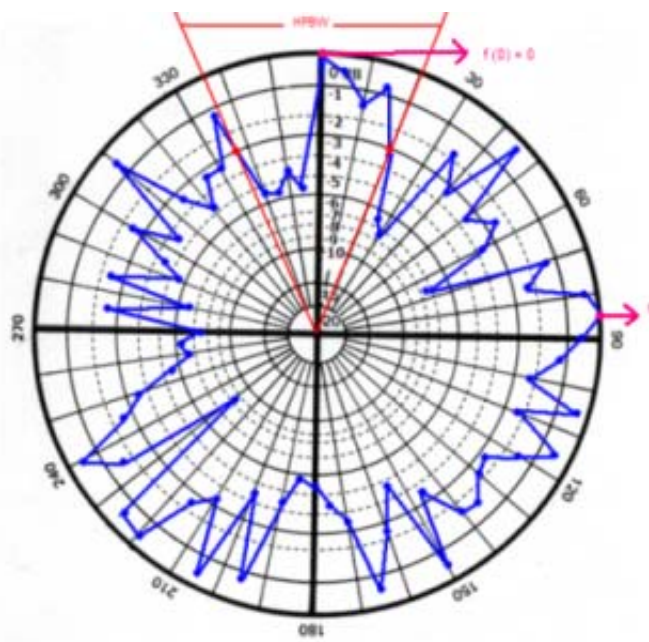

Gambar 9. Pola radiasi pada kanal SCTV tanpa reflektor sudut $90^{\circ}$

Kanal SCTV pada frekuensi 572,25 Mhz menggunakan reflektor sudut $90^{\circ}$

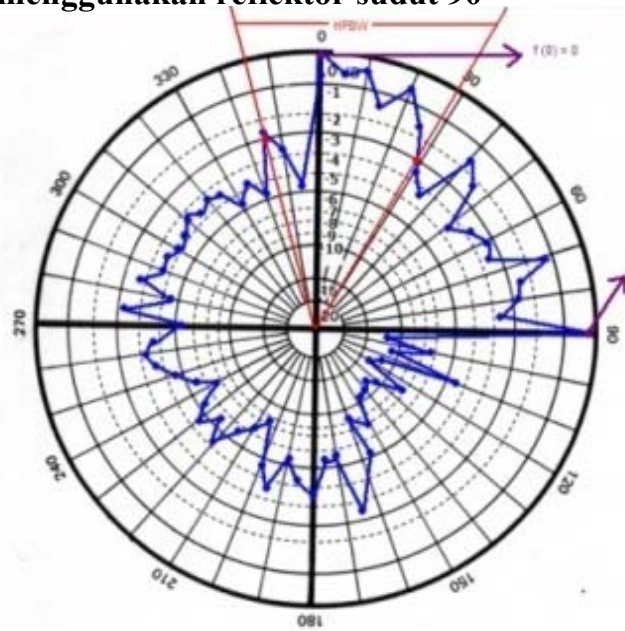

Gambar 10. Pola radiasi pada kanal SCTV menggunakan reflektor sudut $90^{\circ}$

Kanal SBO pada frekuensi 591,25 Mhz tanpa reflektor sudut $90^{\circ}$

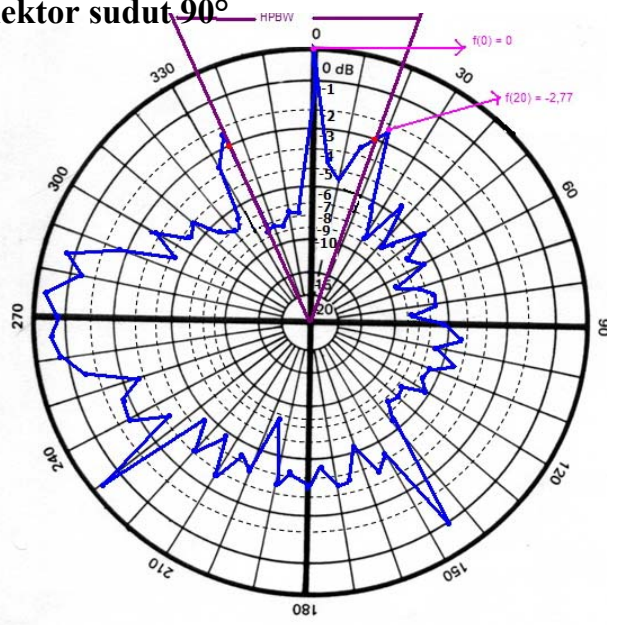

Gambar 11. Pola radiasi pada kanal RCTI tanpa reflektor sudut $90^{\circ}$
Kanal SBO pada frekuensi 591,25

Mhz menggunakan reflektor sudut $90^{\circ}$

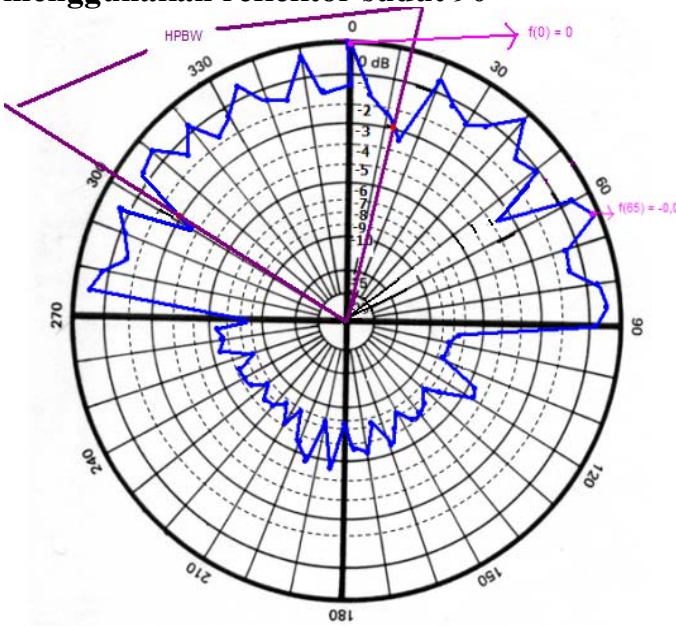

Gambar 12. Pola radiasi pada kanal RCTI tanpa reflektor sudut $90^{\circ}$

Kanal JTV pada frekuensi 783,25 Mhz tanpa reflektor sudut $90^{\circ}$

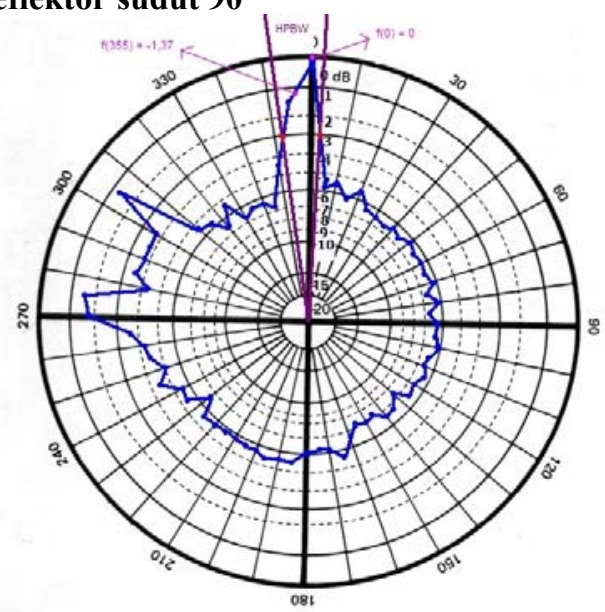

Gambar 13. Pola radiasi pada kanal TPI tanpa reflektor sudut $90^{\circ}$

Kanal JTV pada frekuensi 783,25 $\mathrm{Mhz}$ menggunakan reflektor sudut $90^{\circ}$

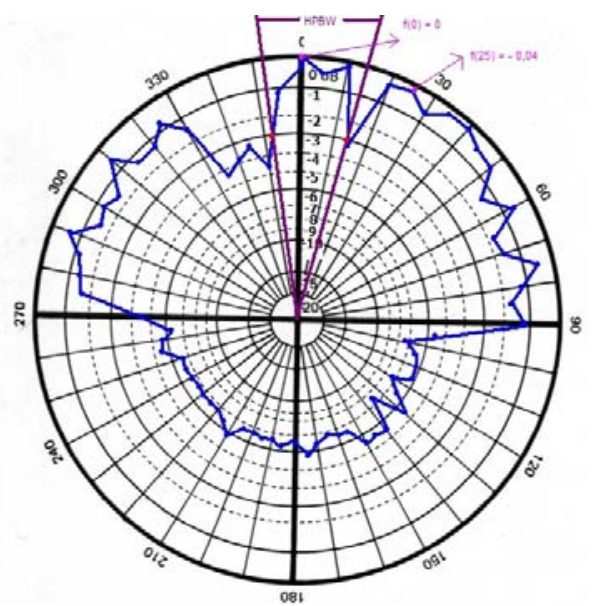

Gambar 14. Pola radiasi pada kanal TPI menggunakan reflektor sudut $90^{\circ}$ 
Kanal Trans7 pada frekuensi 751.25 Mhz tanpa reflektor sudut $90^{\circ}$

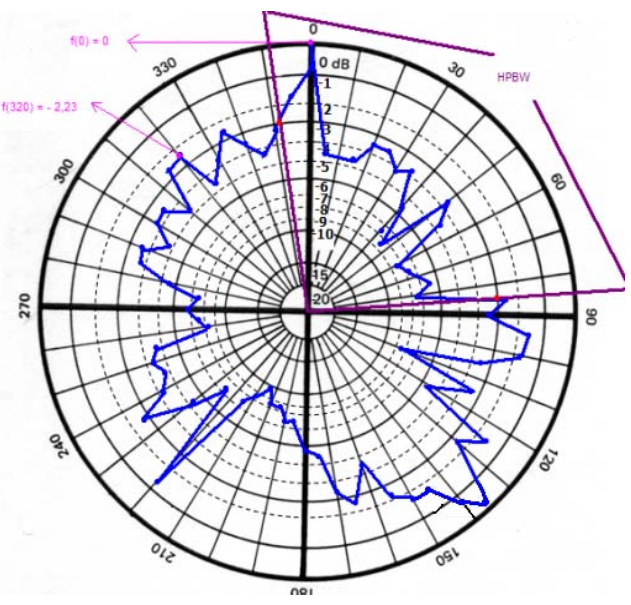

Gambar 15. Pola radiasi pada kanal Indosiar tanpa reflektor sudut $90^{\circ}$

Kanal Trans7 pada frekuensi 751.25 Mhz menggunakan reflektor sudut $90^{\circ}$

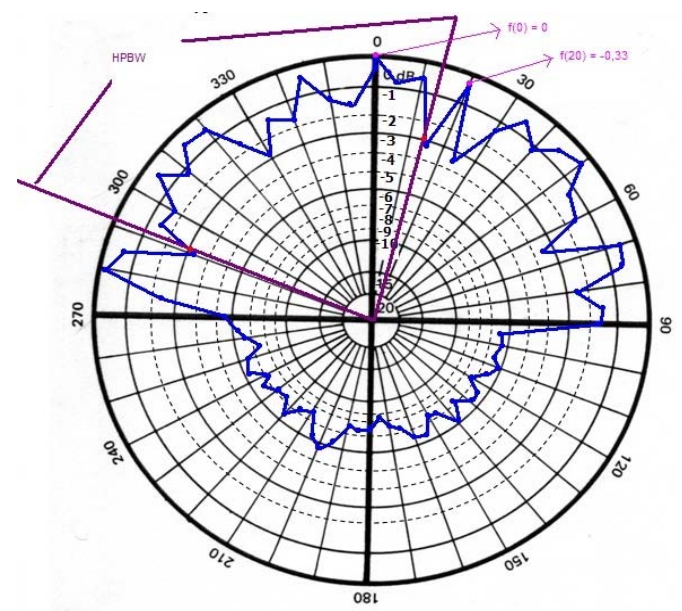

Gambar 16. Pola radiasi pada kanal Indosiar menggunakan reflektor sudut $90^{\circ}$

Kanal ANTV pada frekuensi 495,25 Mhz

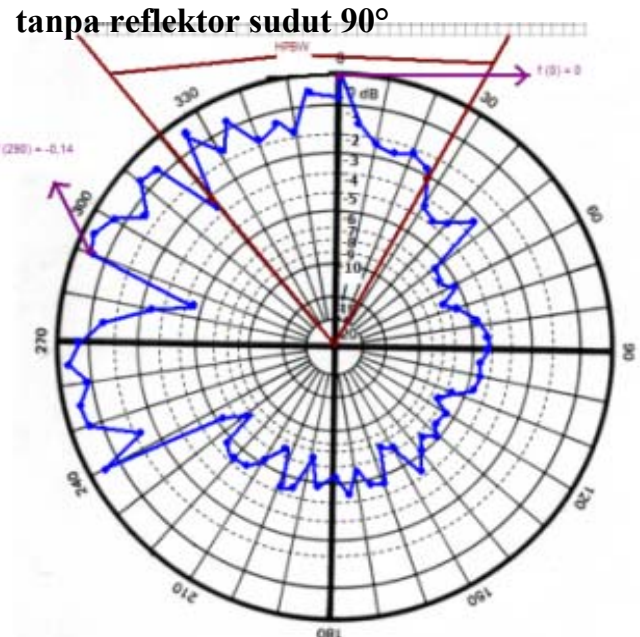

Gambar 17. Pola radiasi pada kanal ANTV tanpa reflektor sudut $90^{\circ}$
Kanal ANTV pada frekuensi 495,25 Mhz menggunakan reflektor $90^{\circ}$

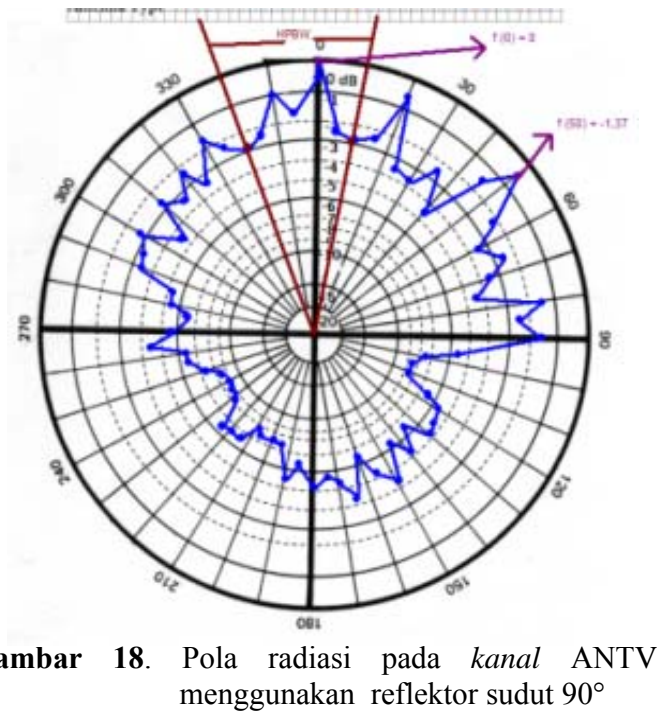

Kanal SpaceT pada frekuensi $676,25 \mathrm{Mhz}$ tanpa reflektor sudut $90^{\circ}$

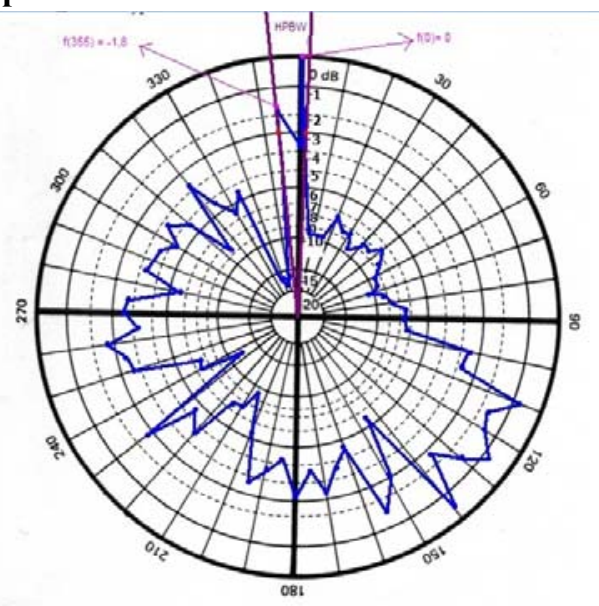

Gambar 19. Pola radiasi pada kanal SpaceT tanpa reflektor sudut $90^{\circ}$

Kanal SpaceT pada frekuensi $676,25 \mathrm{Mhz}$ menggunakan reflektor sudut $90^{\circ}$

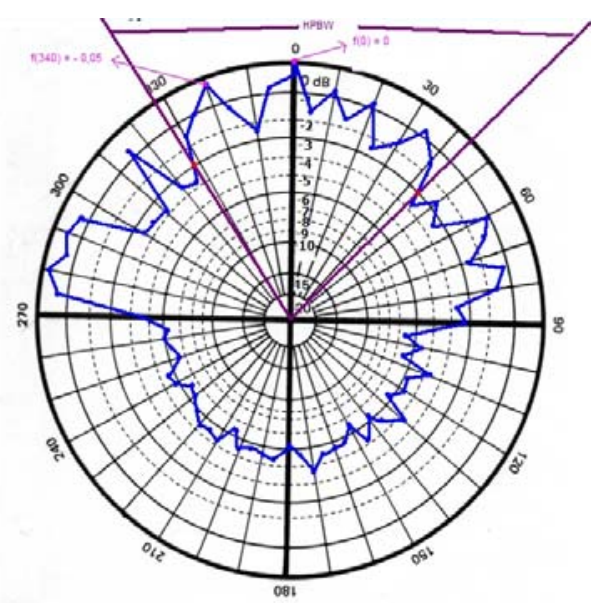

Gambar 20. Pola radiasi pada kanal SpaceT menggunakan reflektor sudut $90^{\circ}$ 
Kanal TVone pada frekuensi 719,25 Mhz tanpa reflektor sudut $90^{\circ}$

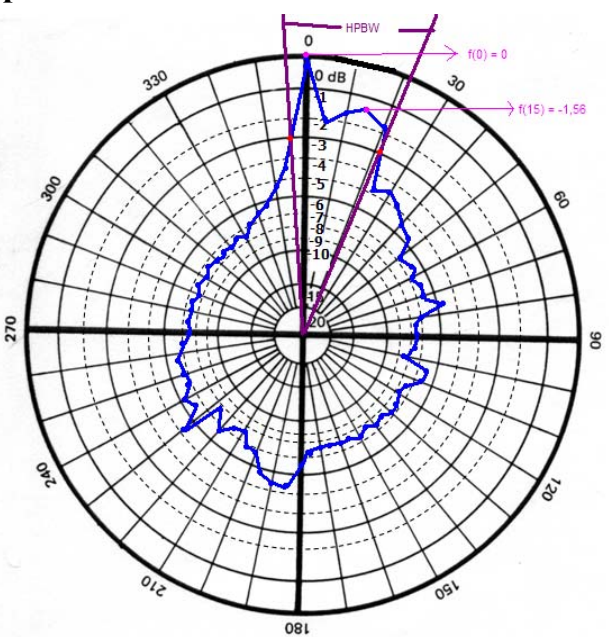

Gambar 21. Pola radiasi pada kanal TVone tanpa reflektor sudut $90^{\circ}$

Kanal TVone pada frekuensi 719,25 Mhz menggunakan reflektor sudut $90^{\circ}$

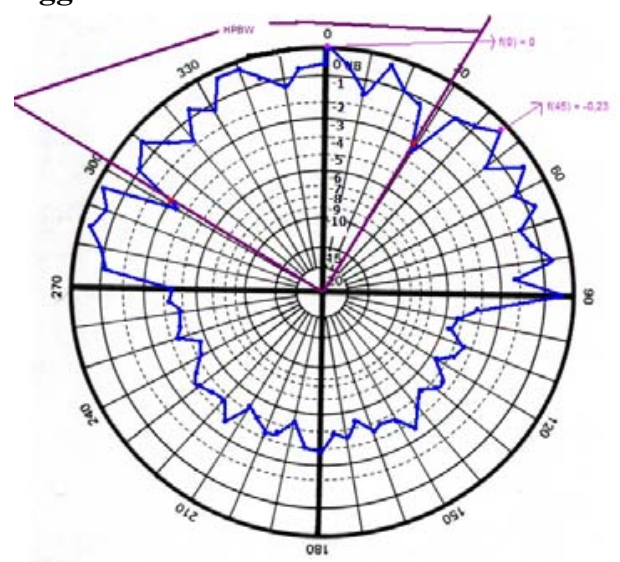

Gambar 22. Pola radiasi pada kanal TVone menggunakan reflektor sudut $90^{\circ}$

Kanal MetroTV pada frekuensi 735,25 Mhz tanpa reflektor sudut $90^{\circ}$

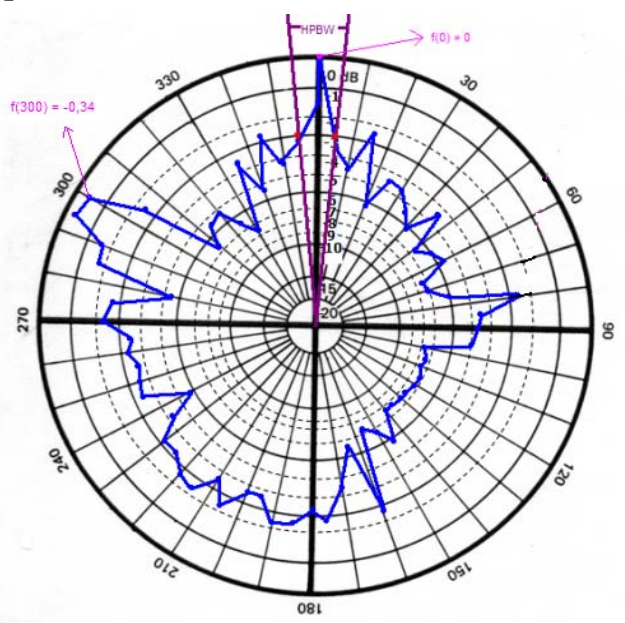

Gambar 23. Pola radiasi pada kanal MetroTV tanpa reflektor sudut 90
Kanal MetroTV pada frekuensi 735,25 Mhz mengunakan reflektor sudut $90^{\circ}$

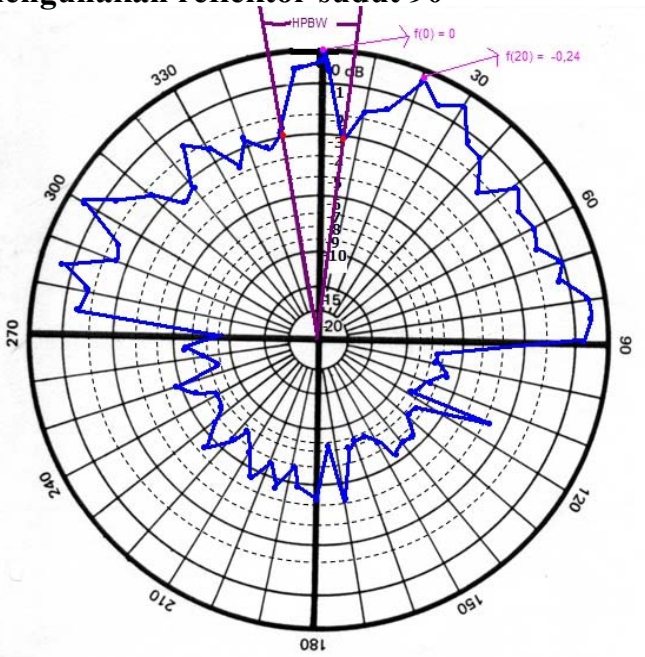

Gambar 24. Pola radiasi pada kanal MetroTV menggunakan reflektor sudut 90

\section{ANALISA}

Setelah melakukan perancangan dan pembuatan antenna Biconical dengan dan tanpa reflektor sudut $90^{\circ}$, selanjutnya dilakukan pengukuran terhadap masing - masing kanal TV dalam frekuensi UHF untuk mengetahui pola radiasinya. Pada tahap ini akan diamati level daya tiap $5^{\circ}$ pergerakan antena dari $0^{\circ}$ sampai $360^{\circ}$ pada frekuensi masing - masing kanal TV yang telah ditentukan, yaitu Trans TV, ANTV, Indosiar, RCTI, TPI, SCTV, SBO, GTV, Tvone, Metro TV, Trans7, Space T, JTV, dan TVRI. Kemudian setelah level daya didapatkan, maka dicari normalisasinya dengan cara hasil pengamatan level daya pada masing - masing kanal TV dikurangi dengan besar level daya saat berada di posisi $0^{\circ}$, sehingga saat posisi $360^{\circ}$ nilai normalisasinya akan sama dengan nol. Namun pada kenyataannya ada beberapa kanal TV yang normalisasinya saat posisi $360^{\circ}$ tidak sama dengan normalisasi saat posisi $0^{\circ}$. Hal tersebut disebabkan pengaruh posisi antena yang berubah - ubah, kondisi lingkungan yang tidak stabil, pengaruh pemasangan reflektor sudut $90^{\circ}$, dan lain sebagainya. Kemudian Dari hasil normalisasi tersebut, maka pola radiasi masing masing kanal TV akan dapat diketahui yaitu apabila menggunakan reflektor sudut maka pola radiasinya directional (single lobe), sebaliknya, apabila tidak menggunakan reflektor sudut maka pola radiasinya omnidirectional (menyebar).

Selanjutnya dari pola radiasi tersebut, maka akan dapat diketahui nilai HPBW (Half power beamwidth) dan side lobe level pada masing masing kanal TV. Untuk HPBWdicari dengan cara mencari lebar sudut yang memisahkan antara dua titik yang mempunyai nilai $-3 \mathrm{~dB}$ dari 
skala puncak pada beam utama. Sehingga akan didapatkan dua nilai, dari side lobe kanan dan kiri, kemudian dijumlahkan. Sedangkan untuk side lobe level, dicari dengan cara mengurangi level daya pada main lobe saat antena berada di posisi $0^{\circ}$ dengan level daya tertinggi yang berada pada side lobe - side lobe levelnya. Dalam hal ini semakin kecil level daya suatu sinyal, pola radiasi yang dihasilkan semakin besar, sehingga gambar TV yang dihasilkan akan semakin bagus, sebaliknya.

Saat antena menggunakan reflektor sudut $90^{\circ}$, maka HPBW terbesar ada pada kanal Trans7, yaitu 94, dan HPBW terkecil berada pada kanal SpaceT, yaitu 9. Sedangkan untuk antena yang tidak menggunakan reflektor sudut $90^{\circ}$, HPBW terbesar ada pada kanal Tvone, yaitu 88, sedangkan HPBW terkecil ada pada kanal MetroTV, yaitu 16. Untuk Side Lobe Level (SLL) terbesar, saat antena menggunakan reflektor sudut $90^{\circ}$ berada pada kanal JTV dan ANTV, yaitu 1,37 dan SLL terkecil berada pada kanal RCTI, yaitu 0,02. Sedangkan saat antena tidak menggunakan reflektor sudut $90^{\circ}$, maka SLL terbesar ada pada kanal SBO, yaitu 2,77, dan SLL terkecil ada pada kanal SCTV, yaitu 0 .

\section{KESIMPULAN}

1. Pola radiasi yang dihasilkan saat menggunakan reflektor sudut $90^{\circ}$ adalah directional, yaitu single lobe, sebaliknya jika tidak menggunakan reflektor sudut $90^{\circ}$ menjadi omnidirectional.

2. Posisi dan letak antenna serta keadaan lingkungan sekitar, sangat mempengaruhi terhadap penangkapan sebuah sinyal TV pada frekuensi UHF.

3. Semakin kecil level daya suatu sinyal, pola radiasi yang dihasilkan akan semakin besar, dan sebaliknya. Misal seperti pada kanal RCTI. Posisi terbaik saat menggunakan reflektor sudut $90^{\circ}$ berada pada posisi $0^{\circ}$ (level daya $=-64,06 \mathrm{dBm}$ ) dan posisi $280^{\circ}$ (level daya $=-64,08 \mathrm{dBm}$ ). Sedangkan posisi terbaik saat tidak menggunakan reflektor sudut $90^{\circ}$ berada pada posisi $0^{\circ}$ (level daya $=-57,69 \mathrm{dBm}$ ) dan pada posisi $55^{\circ}$ (level daya $=-57,92 \mathrm{dBm}$ ).

\section{DAFTAR PUSTAKA}

[1] Balanis, C. A., Antenna Theory: Analysis and Design, Third Edition, John Willey and sons, New York, 2005.

[2] John D Krause., Antennas: Mc Graw-Hill, INC, USA, 1988.

[3] G. H Brown and O. M Woodward,
"Experimentally Determined Radiation Characteristic Of Conical and Trianguler antennas, " RCA Rev., 13,425 - 452, December 1952.

[4] Annisa, R., Visualisasi Pola Radiasi, PENS-ITS, Surabaya, 2005.

[5] Riski Nur Aisya., Desain Implementasi Antena Horn Sektoral Bidang H untuk Link Los Wireless LAN 2,4 Ghz, PENS-ITS, Surabaya, 2008.

[6] http://dono.blog.unsoed.co.id

[7] http://adchotspot.blogspot.com/2009/01/banw idth-antena.html

[7] www.lyngsat.com

[8] GIMANA 2009. New Blog in 2009 Blogger.com

[9] Beccary. Blog pada WordPress.com.

[10]http://internal.physics.uwa.edu.au/ agm/ppft v04.pdf.

[11] www.google.com, Antena Bab1 .

[13] ..., informasi kanal TV di Surabaya, TV One, Surabaya, 2009.

[14] Budi Aswoyo, Bahan Ajar Antena dan Propagasi, PENS - ITS. 